Murat Cikot*, Eyup Gemici, Nilgun Isiksacan, Osman Kones, Pinar Kasapoglu, Sinan Binboga, Elif Binboga, Bahadir Kartal and Halil Alis

\title{
Fibrinopeptide-A and fibrinopeptide-B
}

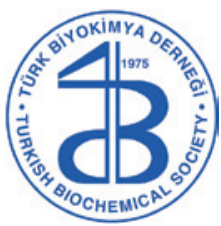
may help to D-dimer as early diagnosis markers for acute mesenteric ischemia Fibrinopeptid-A ve Fibrinopeptid-B, Akut Mesenterik İskemi Erken Tanı Belirteçleri Olarak D-Dimere Yardımcı Olabilir

https://doi.org/10.1515/tjb-2018-0301

Received July 20, 2018; accepted December 11, 2018; previously published online July 18, 2019

\section{Abstract}

Background: The aim of this study was to investigate the importance of fibrinopeptide-A and fibrinopeptide-B, which occur during the formation of D-dimer, the most commonly used laboratory parameter, in the early diagnosis of acute mesenteric ischemia (AMI).

Materials and methods: This experimental study was performed in 30 male pathogen-free Wistar albino rats. The experimental animals were divided into 3 equal groups: Control group $(\mathrm{n}=10)$, Sham group $(\mathrm{n}=10)$ and Ischemia group $(\mathrm{n}=10)$. Blood samples were taken $0,1,3$, and $6 \mathrm{~h}$ after the simulation of mesenteric ischemia.

*Corresponding author: Murat Cikot, Department of General Surgery, Bakirkoy Dr. Sadi Konuk Training and Research Hospital, Istanbul, Turkey, e-mail: muratcikot@hotmail.com

Eyup Gemici, Osman Kones, Sinan Binboga, Bahadir Kartal and Halil Alis: Department of General Surgery, Bakirkoy Dr. Sadi Konuk Training and Research Hospital, Istanbul, Turkey, e-mail: eyupgemici@yahoo.com (E. Gemici); osmankones@gmail.com (O. Kones); dr.binboga@hotmail.com (S. Binboga);

bkartal@hotmail.com (B. Kartal); halilalis@hotmail.com (H. Alis) Nilgun Isiksacan: Department of Biochemistry, Bakirkoy Dr. Sadi Konuk Education and Research Hospital, İstanbul, Turkey, e-mail: nisiksacan@gmail.com. https://orcid.org/0000-00020230-6500

Pinar Kasapoglu: Department of Biochemistry, Bakirkoy Dr. Sadi Konuk Training and Research Hospital, Istanbul, Turkey, e-mail: proxy75@hotmail.com

Elif Binboga: Department of General Surgery, Bagcilar Training and Research Hospital, Istanbul, Turkey, e-mail: elifgur@hotmail.com
Results: Fibrinopeptide-A and fibrinopeptide-B levels increased significantly in the first $6 \mathrm{~h}$ in the ischemic group, similar to the increase in D-dimer levels. The statistical change between $0,1,3$ and $6 \mathrm{~h}$ was more significant for fibrinopeptide-A and fibrinopeptide-B.

Conclusion: Fibrinopeptide-A and fibrinopeptide-B may be markers that can be used for early diagnosis of mesenteric ischemia, early diagnosis is highly important for decreasing mortality and morbidity.

Keywords: Acute mesenteric ischemia; D-dimer; Early diagnosis; Fibrinopeptide A; Fibrinopeptide B.

öz

Amaç: Bu çalışmanın amacı akut mesenterik iskeminin erken tanısında en sık kullanılan laboratuvar parametresi olan D-dimerin oluşumu sürecinde ortaya çıkan Fibrinopetid-A ve Fibrinopeptid-B’ nin önemini araştırmaktır.

Gereç ve Yöntem: $\mathrm{Bu}$ deneysel çalışma 30 erkek-patojen içermeyen Wistar-albino sıçanda gerçekleştirildi. Deney hayvanlar1; Kontrol grubu ( $\mathrm{n}=10)$, Sham grubu $(\mathrm{n}=10)$ ve İskemi grubu $(\mathrm{n}=10)$ olmak üzere 3 eşit gruba ayrıldı. Kan örnekleri mezenterik iskemi uyarımından $0,1,3$ ve 6 saat sonra alındı.

Bulgular: İskemi grubunda ilk 6 saatte Fibrinopeptid-A ve Fibrinopeptid-B düzeyleri D-dimer seviyesindeki artışa benzer şekilde anlamlı olarak arttı. 0., 1., 3., ve 6. saatler arasındaki istatistiksel değişim, daha anlamlı tespit edildi.

Sonuç: Erken tanı mortalite ve morbiditeyi azaltmada çok önemlidir, Fibrinopeptid-A ve Fibrinopeptid-B mezenterik iskemi erken tanısında kullanılabilecek belirteçler olabilir. 
Anahtar kelimeler: Akut Mezenterik İskemi; D-Dimer; Erken Tanı; Fibrinopeptide A; Fibrinopeptide B.

\section{Introduction}

Acute mesenteric ischemia (AMI) has a poor prognosis when accompanied by concomitant diseases. Delayed diagnosis increases mortality. Prognosis is improved when intestinal revascularization and operational intervention can be achieved within $6 \mathrm{~h}$ after ischemia development [1-4].

Serum biomarkers have limited sensitivity and specificity in the diagnosis of AMI. To diagnose intestinal ischemia, elevated levels of biomarkers can only be detected when transmural intestinal infarct has developed [5-9]. Neopterin usually plays a role in cellular immune activation and vascular endothelial damage. Ischemic or septic damages cause elevation of neopterin levels. In a study, neopterin, creatine phosphokinase (CPK), lactate dehydrogenase (LDH), amylase, aspartate aminotransferase (AST), alanine aminotransferase (ALT), and leukocytes levels have been increased according to intestinal wall changes. This elevation was significant at $6-12 \mathrm{~h}$ after the occlusion of superior mesenteric arter (SMA) [10, 11]. In another study, serum LDH and lactate levels with a rising due to prolonged ischemia were significantly higher in all ischemia groups rather than sham. D-dimer, lactate, neopterin and LDH values were investigated in these studies, and concluded that together with radiological examinations, they might help in the early diagnosis of AMI $[12,13]$.

In the last two decades, D-dimer measurement has become more important when thrombotic pathologies are suspected. D-dimer is a fibrin degradation product. Fibrin polymer generation requires two enzymatic pathways, whereas fibrin degradation products require only one. Thrombin cleaves fibrinogen into fibrinopeptide A, B, and E, known as fibrin monomers [14-17].

The aim of the study was to evaluate the fibrin monomer synthesis intermediate products fibrinopeptide $A$ and $B$ in the early phase (first $6 \mathrm{~h}$ ) of mesenteric ischemia and to investigate their correlation with D-dimer levels.

\section{Materials and methods}

\section{Experimental design}

Approval for the study was obtained from the Ethical Committee University of Health Sciences, Bagcilar Education and Research Hospital for animal experimental design
(March 30 2016, \#07/2016). Thirty male pathogen-free Wistar albino rats were included in this study. Weights of rats ranged between 200 and $210 \mathrm{~g}$. All rats were kept in the laboratory minimum for 1 week before the experiment in order to keep them away from stress and to provide optimum acclimatization. All rats were kept in large cages and were given food and water ad libitum. Rats were randomized into three groups: Control group $(\mathrm{CG})$ : $(n=10)$; Sham group (SG): $(n=10)$; and Ischemia group $(\mathrm{IG}):(\mathrm{n}=10)$.

\section{Surgical procedure}

Mesenteric ischemia was simulated using a SMA occlusion model. Thirty rats were anesthetized with an intraperitoneal injection of ketamine $(50 \mathrm{mg} / \mathrm{kg})$ and xylazine $(10 \mathrm{mg} / \mathrm{kg})$. After abdominal skin shaving and abdominal wall disinfection with povidone-iodine solution, rats were placed in the supine position, and a $2 \mathrm{~cm}$ midline incision was created in the abdominal wall to access the abdominal cavity in the SG and IG. The abdominal wall was closed using a 3/0 prolene suture. Venipuncture was performed from the $\mathrm{CG}$ at $0,1,3$ and $6 \mathrm{~h}$ without any operation. The first blood sample after laparotomy was taken from the tail vein, and the laparotomy was subsequently closed in the SG. Blood samples were taken at 1, 3 and $6 \mathrm{~h}$. In the IG, the SMA was located and ligated with $4 / 0$ silk for generating the ischemia model, and the laparotomy was closed after the first blood sample was taken from the tail vein. Blood samples were taken at 1, 3 and $6 \mathrm{~h}$. All rats were sacrificed by exsanguination at the 6 th $\mathrm{h}$.

\section{Biochemical analysis}

Venous blood samples were collected by venipuncture directly into plain and K2EDTA tubes. Serum and plasma separation was performed after centrifugation of blood samples at $1500 \mathrm{~g}$ for $15 \mathrm{~min}$. All specimens were kept frozen at $-20^{\circ} \mathrm{C}$ until analysis. Serum samples were analyzed for D-dimer ( $\mu \mathrm{g} \mathrm{FEU/mL)} \mathrm{levels} \mathrm{using} \mathrm{a} \mathrm{Cobas} \mathrm{c501}$ analyzer (Roche Diagnostics, Switzerland), and plasma samples were assayed for fibrinopeptides A and B $(\mu \mathrm{g} / \mathrm{mL})$ measurement with an ELISA kit (Mybiosource Inc., USA) using a Triturus analyzer (Grifols International, Spain) according to the manufacturer's instructions.

\section{Pathological assessment}

Small intestines are evaluated blindly, whereas all tissues were coded earlier. Tissues were considered normal (Figure 1) or ischemic (Figure 2). Ischemic damage of the 


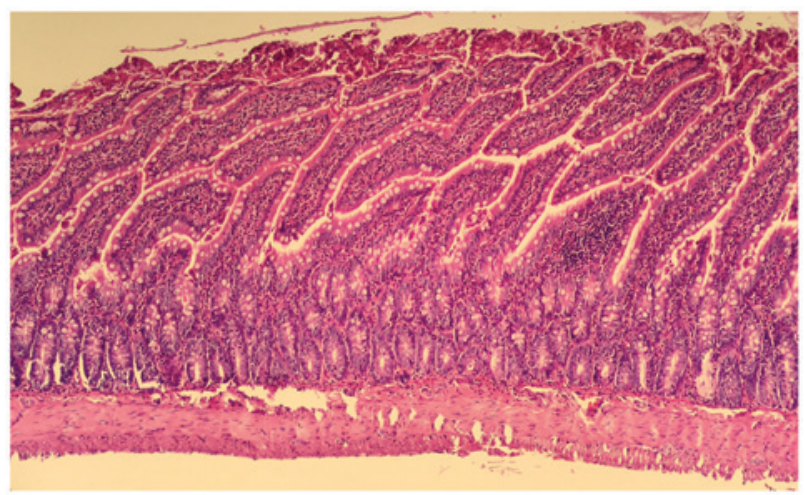

Figure 1: Normal intestinal mucosa.

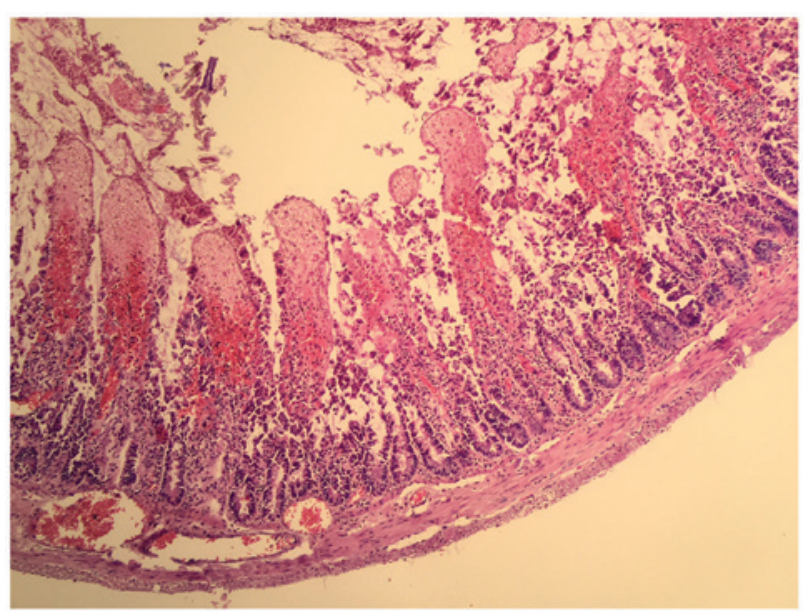

Figure 2: Ischemic intestinal mucosa.

small intestines was classified using microscopic evaluation, hematoxylin-eosin staining and the Chiu/Park scale [18].

\section{Statistical analysis}

SPSS version 23.0 statistical package program was used for the analysis of the data. Mean, standard deviation, median and quartile (IRQ) values for quantitative data were recorded. The normal distribution test of the quantitative variables was performed by the Kolmogorov-Smirnov test. The Friedman test was used for the dependent variable analysis. Mann-Whitney U and Kruskal Wallis H tests were used in two independent group and multiple independent group comparisons, respectively. The Mann-Whitney U test (Dunn Multiple Comparison) and the Wilcoxon Sign Test (Bonferroni Correction) were used for binary comparisons. A $p<0.05$ value was considered to be statistically significant.

\section{Results}

There were significant differences in fibrinopeptide-A $(p=0.0001)$, fibrinopeptide-B $(p=0.0001)$ and $D$-dimer levels in the IG according to time. As a result of Dunn's multiple comparison tests, it was observed that the levels of fibrinopeptide A and B in the IG were significantly higher at 3 and $6 \mathrm{~h}$ than they were at $0 \mathrm{~h}$. Fibrinopeptide $A$ and $B$ levels between 0 and $3 \mathrm{~h}(\mathrm{p}=0.022$ and $\mathrm{p}=0.003$, respectively) and between 0 and $6 \mathrm{~h}(\mathrm{p}=0.0001$ and $p=0.0001$, respectively) were significantly elevated.

It was observed that $\mathrm{D}$-dimer levels differed significantly between 1 and $3 \mathrm{~h}(\mathrm{p}=0.016)$ and between 1 and $6 \mathrm{~h}(\mathrm{p}=0.0016)$. The concentration values of $\mathrm{D}$-dimer at 3 and $6 \mathrm{~h}$ were found to be higher than those at $1 \mathrm{~h}$ (Table 1).

Differences in fibrinopeptide-A concentration values in all-time combination without $0 \mathrm{~h}-1 \mathrm{~h}$ were observed to be statistically significant between the CG and the IG $(\mathrm{p}<0.05) .1 \mathrm{st}$, 3rd, 6th $\mathrm{h}$ concentration values of fibrinopeptide-A between the SG and the IG were found to be statistically significant compared to values at $0 \mathrm{~h}$. These data are summarized in Table 2.

Differences of fibrinopeptide-B concentration values in all time combinations without 3rd-6th $\mathrm{h}$ were observed to be statistically significant between the IG and the CG $(p<0.05)$, and between the IG and the SG $(p<0.05)$. These data are summarized in Table 3.

D-dimer concentration values between the 1st and 6th $h$ were observed to be statistically significant between the CG and the IG $(\mathrm{p}=0.005)$ (Table 4).

\section{Discussion}

Acute mesenteric ischemia is a lethal vascular disease. Mortality is reported as $50 \%-80 \%$, whereas early diagnosis and treatment decrease mortality. D-dimer has a sensitivity between $93 \%$ and $95 \%$ and a specificity of 50\% for the diagnosis of thromboembolism [2, 19-23]. Negative results of D-dimer can exclude thrombosis, [24, 25] but early or delayed venipuncture, liver diseases, inflammation, malignancy, trauma, pregnancy, recent surgical operations, high levels of rheumatoid factor and aging may cause false-negative results.

Further investigations are needed regarding the relation between positive D-dimer levels and phases of AMI. Our study aimed to evaluate the usefulness of fibrinopeptide-A and B levels and D-dimer levels at $6 \mathrm{~h}$ of AMI.

When each marker was evaluated by itself, significant increases in all groups and times of fibrinopeptide-A and 


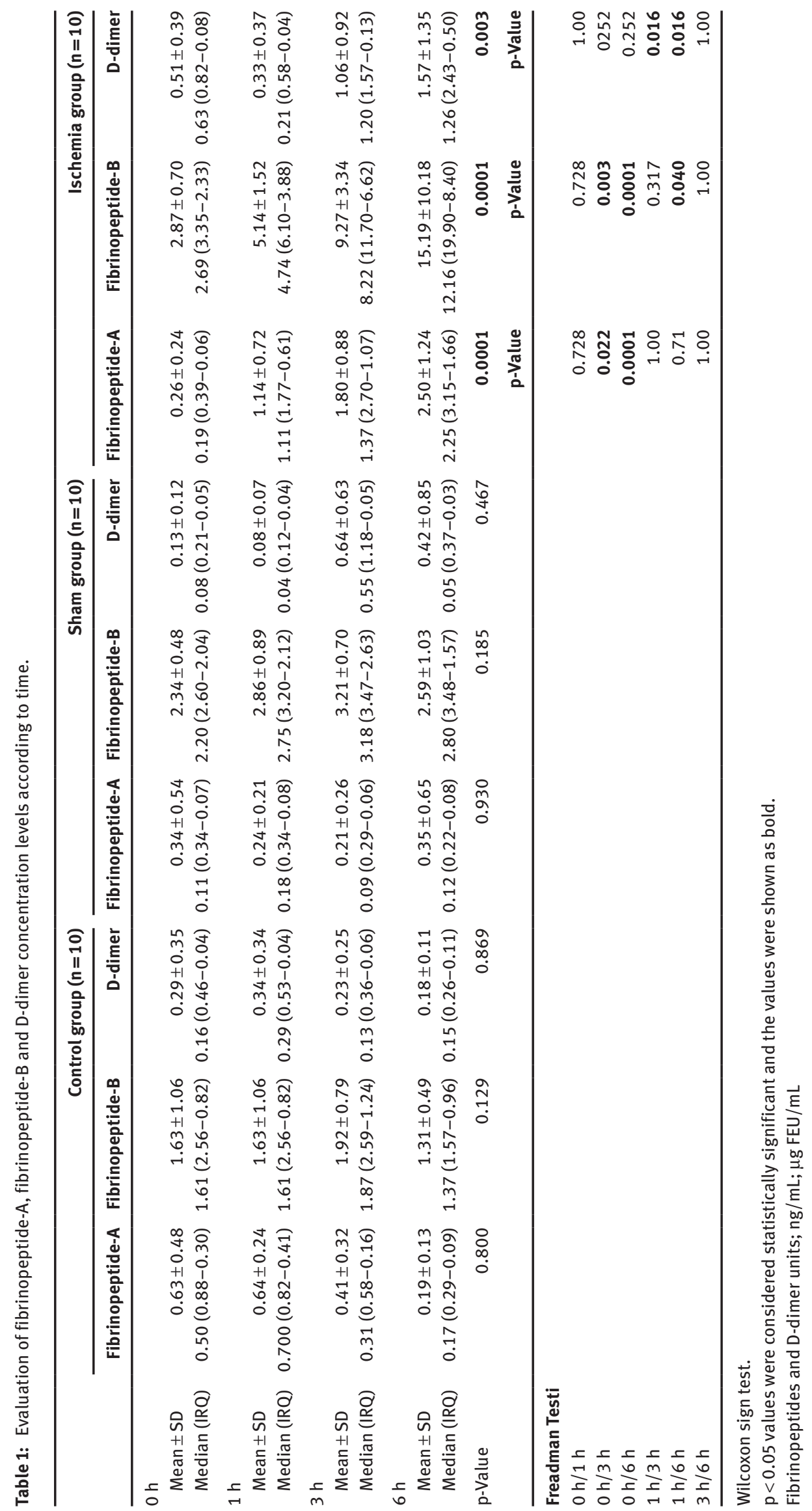


Table 2: Evaluation of fibrinopeptide-A concentration levels according to time in control, sham and ischemia group.

\begin{tabular}{|c|c|c|c|c|c|c|}
\hline \multirow[t]{2}{*}{ Hour } & \multirow[b]{2}{*}{$0-1$} & \multirow[b]{2}{*}{$0-3$} & \multirow[b]{2}{*}{$0-6$} & \multirow[b]{2}{*}{$1-3$} & \multicolumn{2}{|c|}{ Fibrinopeptide $A(\mathrm{ng} / \mathrm{mL})$} \\
\hline & & & & & $1-6$ & $3-6$ \\
\hline \multicolumn{7}{|c|}{ Control group $(n=10)$} \\
\hline Mean \pm SD & $0.01 \pm 0.45$ & $0.22 \pm 0.61$ & $0.44 \pm 0.38$ & $0.23 \pm 0.54$ & $0.44 \pm 0.26$ & $0.22 \pm 0.31$ \\
\hline Median (IRQ) & $0.07(0.34-0.24)$ & $0.04(0.55-0.17)$ & $0.38(0.62-0.16)$ & $0.43(0.63-0.17)$ & $0.55(0.63-0.23)$ & $0.20(0.40-0.03)$ \\
\hline \multicolumn{7}{|c|}{ Sham group $(n=10)$} \\
\hline Mean \pm SD & $0.10 \pm 0.40$ & $0.12 \pm 0.55$ & $0.02 \pm 0.17$ & $0.02 \pm 0.34$ & $0.12 \pm 0.50$ & $0.14 \pm 0.63$ \\
\hline Median (IRQ) & $0.04(0.16-0.11)$ & $0.006(0.29-0.04)$ & $0.01(0.06-0.08)$ & $0.13(0.22-0.08)$ & $0.005(0.12-0.09)$ & $0.03(0.09-0.15)$ \\
\hline \multicolumn{7}{|c|}{ Ischemia group $(\mathrm{n}=10)$} \\
\hline Mean \pm SD & $0.88 \pm 0.77$ & $1.55 \pm 0.88$ & $2.25 \pm 1.15$ & $0.67 \pm 0.46$ & $1.37 \pm 0.79$ & $0.70 \pm 0.89$ \\
\hline Median (IRQ) & $0.98(0.26-1.39)$ & $1.07(0.89-2.31)$ & $2.18(1.32-3.04)$ & $0.83(0.35-1.02)$ & $1.21(0.94-1.58)$ & $0.47(0.02-1.51)$ \\
\hline $\mathrm{p}$-Value & 0.024 & 0.000 & 0.000 & 0.007 & 0.000 & 0.043 \\
\hline \multicolumn{7}{|c|}{ Kruskall Wallis $\mathrm{H}$ test } \\
\hline Control/Sham & 1.00 & 1.00 & 0.198 & 1.000 & 0.132 & 0.572 \\
\hline Control/Ischemia & 0.102 & 0.002 & 0.0001 & 0.008 & 0.0001 & 0.036 \\
\hline Sham/Ischemia & 0.033 & 0.002 & 0.040 & 0.053 & 0.102 & 0.688 \\
\hline
\end{tabular}

Dunn's Multiple Comparation.

$\mathrm{p}<0.05$ values were considered statistically significant and the values were shown as bold.

Table 3: Evaluation of fibrinopeptide-B concentration levels according to time in control, sham and ischemia group.

\begin{tabular}{|c|c|c|c|c|c|c|}
\hline \multirow[t]{2}{*}{ Hour } & \multirow[b]{2}{*}{$0-1$} & \multirow[b]{2}{*}{$0-3$} & \multirow[b]{2}{*}{$0-6$} & \multirow[b]{2}{*}{$1-3$} & \multicolumn{2}{|c|}{ Fibrinopeptide B $(\mathrm{ng} / \mathrm{mL})$} \\
\hline & & & & & $1-6$ & $3-6$ \\
\hline \multicolumn{7}{|c|}{ Control group $(n=10)$} \\
\hline Mean \pm SD & $0.00 \pm 0.00$ & $0.29 \pm 1.15$ & $0.32 \pm 1.07$ & $0.29 \pm 1.15$ & $0.32 \pm 1.07$ & $0.61 \pm 0.56$ \\
\hline Median (IRQ) & $0.00(0.00-0.00)$ & $0.73(0.58-1.18)$ & $0.06(1.46-0.48)$ & $0.73(0.58-1.18)$ & $0.06(1.46-0.48)$ & $0.58(1.04-0.19)$ \\
\hline \multicolumn{7}{|c|}{ Sham group $(n=10)$} \\
\hline Mean \pm SD & $0.51 \pm 1.18$ & $0.87 \pm 0.77$ & $0.25 \pm 1.21$ & $0.35 \pm 0.96$ & $0.26 \pm 0.83$ & $0.62 \pm 0.96$ \\
\hline Median (IRQ) & $0.29(0.50-1.24)$ & $0.71(0.40-0.98)$ & $0.46(0.82-1.21)$ & $0.61(0.26-1.17)$ & $0.38(0.92-0.03)$ & $0.76(1.15-0.26)$ \\
\hline \multicolumn{7}{|c|}{ Ischemia group $(\mathrm{n}=10)$} \\
\hline Mean \pm SD & $2.27 \pm 1.47$ & $6.40 \pm 3.45$ & $12.32 \pm 10.19$ & $4.13 \pm 3.19$ & $10.05 \pm 10.24$ & $5.92 \pm 10.75$ \\
\hline Median (IRQ) & $1.73(1.11-3.58)$ & $5.17(3.98-9.20)$ & $8.97(5.55-16.84)$ & $2.67(2.15-5.66)$ & $6.31(4.16-13.26)$ & $4.02(0.77-8.19)$ \\
\hline$p$-Value & 0.003 & 0.000 & 0.000 & 0.000 & 0.001 & 0.146 \\
\hline \multicolumn{7}{|c|}{ Kruskall Wallis $\mathrm{H}$ test } \\
\hline Control/Sham & 1.000 & 1.000 & 1.000 & 1.000 & 1.000 & \\
\hline Control/Ischemia & 0.006 & 0.001 & 0.0001 & 0.002 & 0.007 & \\
\hline Sham/Ischemia & 0.019 & 0.003 & 0.008 & 0.002 & 0.003 & \\
\hline
\end{tabular}

Dunn's Multiple Comparation.

$\mathrm{p}<0.05$ values were considered statistically significant and the values were shown as bold.

fibrinopeptide-B were detected, while D-dimer level variations at $6 \mathrm{~h}$ of AMI were not significant. A statistically significant difference was observed between the 1st and 6th $\mathrm{h}$ of the control and the ischemic group's D-dimer levels, but this difference was not as substantial as the statistical change in fibrinopeptide-A and fibrinopeptide-B.

Early diagnosis is highly important in AMI, where the mortality rate can be reduced from between $70 \%$ and $90 \%$ to $50 \%$. It is not known exactly how helpful the most commonly used D-dimer is in the first $6 \mathrm{~h}$ of diagnosis.
As mentioned above, negativity of D-dimer can be observed in early blood samples taken at the beginning of AMI, which is the result of this experimental study. According to the data in our study, this negativity risk was not observed for fibrinopeptide-A and fibrinopeptide-B. We determined that fibrinopeptide-A and fibrinopeptide-B may supplement D-dimer as an AMI detection marker. Moreover, fibrinopeptides may be more valuable than D-dimer in the early phase of AMI. Furthermore, D-dimer levels may not be elevated, despite the early phase of mesenteric ischemia 
Table 4: Evaluation of D-dimer concentration levels according to time in control, sham and ischemia group.

\begin{tabular}{|c|c|c|c|c|c|c|}
\hline \multirow[t]{2}{*}{ Hour } & \multirow[b]{2}{*}{$0-1$} & \multirow[b]{2}{*}{$0-3$} & \multirow[b]{2}{*}{$0-6$} & \multirow[b]{2}{*}{$1-3$} & \multicolumn{2}{|c|}{ D-dimer $(\mu \mathrm{g} \mathrm{FEU} / \mathrm{mL}$ ) } \\
\hline & & & & & $1-6$ & $3-6$ \\
\hline \multicolumn{7}{|c|}{ Control group $(n=10)$} \\
\hline Mean \pm SD & $0.05 \pm 0.09$ & $0.06 \pm 0.45$ & $0.11 \pm 0.38$ & $0.11 \pm 0.43$ & $0.16 \pm 0.38$ & $0.05 \pm 0.29$ \\
\hline Median (IRQ) & $0.00(0.00-0.10)$ & $0.08(0.36-0.27)$ & $0.05(0.34-0.19)$ & $0.08(0.45-0.24)$ & $0.21(0.37-0.19)$ & $0.09(0.20-0.17)$ \\
\hline \multicolumn{7}{|c|}{ Sham group $(n=10)$} \\
\hline Mean \pm SD & $0.05 \pm 0.17$ & $0.51 \pm 0.58$ & $0.29 \pm 0.89$ & $0.56 \pm 0.67$ & $0.34 \pm 0.87$ & $0.22 \pm 1.26$ \\
\hline Median (IRQ) & $0.03(0.16-0.07)$ & $0.42(0.00-0.88)$ & $0.03(0.19-0.35)$ & $0.49(0.06-1.15)$ & $0.02(0.05-0.28)$ & $0.48(1.16-0.34)$ \\
\hline \multicolumn{7}{|c|}{ Ischemia group $(n=10)$} \\
\hline Mean \pm SD & $0.17 \pm 0.39$ & $0.55 \pm 0.99$ & $1.06 \pm 1.30$ & $0.73 \pm 0.98$ & $1.23 \pm 1.17$ & $0.51 \pm 1.99$ \\
\hline Median (IRQ) & $0.04(0.43-0.01)$ & $0.28(0.08-0.93)$ & $0.49(0.06-2.12)$ & $0.83(0.08-1.04)$ & $1.03(0.29-1.92)$ & $0.00(0.25-1.54)$ \\
\hline $\mathrm{p}$-Value & 0.125 & 0.129 & 0.076 & 0.066 & 0.006 & 0.539 \\
\hline \multicolumn{7}{|c|}{ Kruskall Wallis $\mathrm{H}$ test } \\
\hline Control/Sham & & & & & 0.819 & \\
\hline Control/Ischemia & & & & & 0.005 & \\
\hline Sham/Ischemia & & & & & 0.121 & \\
\hline
\end{tabular}

Dunn's Multiple Comparation.

$\mathrm{p}<0.05$ values were considered statistically significant and the values were shown as bold.

(hence it is called negativity), though severe mesenteric ischemia may result later in the day. Also, in a prospective study by Ghafouri et al. ischemia was not determined by computed tomography (CT) angiography in 43 patients while it was in 27 patients. D-dimer levels were not elevated in AMI compared to non-AMI $(\mathrm{p}=0.256)$. This study supports that AMI may not cause significant D-dimer elevations. Furthermore Aydin et al. revealed that the D-dimer levels were not increased according to mesenteric ischemia and D-dimer is not suitable for early diagnosis of AMI [26, 27].

This animal study provides noticeable finding for the clinical assessment of AMI. Combined laboratory findings of some markers as neopterin, D-dimer, fibrinopeptides may be more valuable for the early diagnosis of AMI [10].

Our study had some limitations including hemolysis, coagulation and the amount of in taking blood according to surgical stress during the blood intake from rats' vein. They solved in time and the operation was completed successfully.

D-dimer is routinely used in diagnosis of mesenteric ischemia, but our results suggest that the combination of D-dimer and fibrinopeptide is more effective. Although fibrinopeptide analyses are more expensive than D-dimer and the combination will increase the costs, the diagnosis and treatment of mesenteric ischemia cost higher than laboratory analyses. It is expected that costs for diagnosis of mesenteric ischemia will decrease, when fibrinopeptide levels are measured routinely in clinical laboratories.

The results of our work cannot be confirmed in humans by prospective randomized trials. Nevertheless, this experimental study clearly demonstrates that fibrinopeptide-A and fibrinopeptide-B can be used in combination with D-dimer and that they are useful for the early detection of AMI, particularly in the early phase of AMI when AMI is not clinically severe.

\section{Conclusion}

Fibrinopeptide-A and fibrinopeptide-B may be markers that can be used for early diagnosis of mesenteric ischemia, and early diagnosis is highly important for decreasing mortality and morbidity.

Funding: This research did not receive any specific grant from funding agencies in the public, commercial, or notfor-profit sectors.

Declaration of interest: The authors report no conflicts of interest. The authors alone are responsible for the content and writing of the paper.

\section{References}

1. Scheider TA, Longo WE, Ure T, Verrnava AM. Mesenteric ischemia: acute arterial syndromes. Dis Colon Rectum 1994;37:1163-74.

2. Yasuhara H. Acute mesenteric ischemia: the challenge of gastroenterology. Surg Today 2005;35:185-95.

3. Wilson C, Gupta R, Gilmour DG, Imrie CW. Acute superior mesenteric ischemia. Br J Surg 1987;74:279-81. 
4. Lobo-Martinez E, Merono CE, Sacco O, Martinez ME. Embolectomy in mesenteric ischemia. Rev Esp Enferm Dig 1993;83:351-4.

5. Kaleya RN, Boley SJ. Acute mesenteric ischemia. Crit Care Clin 1995;11:479-512.

6. Brandt LJ, Boley SJ. AGA technical review on intestinal ischemia. Gastroenterology 2000;118:954-68.

7. Bassiouny HS. Nonocclusive mesenteric ischemia. Surg Clin North Am 1997;77:319-26.

8. Reilly PM, Bulkley GB. Vasoactive mediators and splanchnic perfusion. Crit Care Med 1993;21:55-68.

9. Kim EH, Gewertz BL. Chronic digitalis administration alters mesenteric vascular reactivity. J Vasc Surg 1987;5:382-9.

10. Coskun A, Halici Z, Oral A, Bayir Y, Deniz F, Caycı T, et al. The value of combined elevation of $D$-dimer and neopterin as a predictive parameter for early stage acute mesenteric ischemia: an experimental study. Vascular 2017;25:163-9.

11. Pierrakos C, Vincent JL. Sepsis biomarkers: a review. Crit Care 2010;14:R15.

12. Demir IE, Ceyhan GO, Friess H. Beyond lactate: is there a role for serum lactate measurement in diagnosing acute mesenteric ischemia? Dig Surg 2012;29:226-35.

13. Cakir M, Yildirim D, Sarac F, Donmez T, Mirapoglu S, Hut A, et al. In the experimental model of acute mesenteric ischemia, the correlation of blood diagnostic parameters with the duration of ischemia and their effects on choice of treatment. J Invest Surg 2018;31:1-8.

14. John AS, Tuerff SD, Kerstein MD. Nonocclusive mesenteric infarction in hemodialysis patients. J Am Coll Surg 2000;190:84-8.

15. Tripodi A. D-dimer testing in laboratory practice. Clin Chem 2011;57:1256-62.

16. Solak ZA, Telli CG, Kabaroglu C, Dogan B, Bayindir U, Erdener D, et al. Pulmoner Emboli Tanisinda D-Dimer Testinin Yeri. Solunum Hastalıklari 2003;14:11-6.
17. Wakai A, Gleeson A, Winter D. Role of fibrin D dimer testing in emergency medicine. Emerg Med J 2003;20:319-25.

18. Oltean M, Olausson M. The Chiu/Park scale for grading intestinal ischemia-reperfusion: if it ain't broke don't fix it! Intensive Care Med 2010;36:1095.

19. Batellier J, Keny R. Superior mesenteric artery embolism eightytwo cases. Ann Vasc Surg 1990;4:112-6.

20. Boley SJ, Feinstein FR, Sammartano R, Brandt LJ. New concept in the management of emboli of the superior mesenteric artery. Surg Gynecol Obstet 1981;153:561-9.

21. Oldenburg WA, Lau LL, Rodenberg TJ, Edmonds HJ, Burger CD. Acute mesenteric ischemia: a clinical review. Arch Intern Med 2004;164:1054-62.

22. Berland T, Oldenburg WA. Acute mesenteric ischemia. Curr Gastroenterol Rep 2008;10:341-6.

23. Stamatakos M, Stefanaki C, Mastrokalos D, Arampatzi H, Safioleas P, Chatziconstantinou C, et al. Mesenteric ischemia: still a deadly puzzle for the medical community. Tohoku J Exp Med 2008;216:197-204.

24. Rathbun SW, Whitsett TL, Raskob GE. Negative D-dimer result to exclude recurrent deep venous thrombosis: a management trial. Ann Intern Med 2004;141:839-45.

25. Acosta S, Nilsson TK, Björck M. Preliminary study of D-dimer as a possible marker of acute bowel ischaemia. Br J Surg 2001;88:385-8.

26. Ghafouri RR, Shahbazi S, Gholipour C, Shams-Vahdati S, Khoshbaten M, Ghaffarzad A, et al. The value of lab findings in early diagnosis of acute mesenteric ischemia. J Emerg Pract Trauma 2016;2:46-9.

27. Aydin B, Ozban M, Serinken M, Kaptanoglu B, Demirkan NC, Aydin C. The place of D-dimer and L-lactate levels in the early diagnosis of acute mesenteric ischemia. Bratisl Lek Listy 2015;116:343-50. 